\title{
UČINKOVIT MENEDŽMENT ZNANIA KOT PODLAGA ZA CELOSTEN ZNANJSKI INŽENIRING Znanje kot ključni kapital organizacije
}

Mag. Svetlana Lazović

Razvojna agencija

Savinjske regije

\section{POVZETEK}

Menedžment znanja v ospredje postavlja človeške vire in načrtno zvišuje njihovo vrednost. Vočeh sodobnih menedžerjev znanje pomeni najvišjo vrednoto. Učinkovito vodenje in upravljanje procesov znanja je njihova osrednja dejavnost; hkrati je tudi najvidnejša značilnost znanjskih organizacij. Znanje, podobno kot inovativnost in ustvarjalnost, je treba spodbujati in z njim ravnati na primerne načine. Zavezanost $k$ pridobivanju novega znanja je odvisna od upravljanja medsebojnih odnosov, zato so skrbniki znanjskih procesov, t. i. sodobni menedžerji znanja, usmerjeni $k$ vzpostavljanju partnerskih odnosov z vsemi člani organizacije. V središču partnerskega odnosa so posameznikove kompetence in ustvarjalna izraba znanja. Vodenje $v$ znanjskih organizacijah s spodbujanjem $k$ učenju, razpravi in medsebojni izmenjavi mnenj, ne nazadnje pa k osebnostnemu in profesionalnemu razvoju zaposlenih, izboljšuje kakovost dela. Slednje rezultira $v$ razvijanju novih znanj in dvigu konkurenčnosti.

Ključne besede: menedžment znanja, znanjske organizacije, izobraževalni menedžment, menedžerji znanja

\section{EFFECTIVE KNOWLEDGE MANAGEMENT AS BASIS FOR HOLISTIC KNOWLEDGE ENGINEERING - KNOWLEDGE AS THE KEY ASSET OF AN ORGANIZATION - ABSTRACT}

\begin{abstract}
In knowledge management, human resources are in the foreground and their value is constantly rising. In the eyes of modern managers knowledge is the key asset of an organization. Effective management and management of knowledge processes are central preoccupations of modern managers and, at the same time, the most prominent feature of a knowledge-based organization. Like innovation and creativity, knowledge needs to be encouraged and treated with due care. Committment to aquisition of new knowledge depends on how the interpersonal relationships are managed in an organization, therefore, those responsible for knowledge processes, the so-called modern knowledge managers, will develop partnership relationships with all members of their organization. In the core of such partnerships lie competences of individual employees and their creative application of knowledge. By encouraging learning, discussions and opinion exchange as well as personal and professional growth of their employees, management in knowledge-based organizations is improving the quality of work, and consequently, generation of new knowledge and their organization's competitive advantage.
\end{abstract}

Keywords: knowledge management, knowledge-based organizations, educational management, knowledge managers

UDK: $331.108 .45: 374.7$

\section{UVOD}

V današnjem spreminjajočem se svetu težko govorimo o kakšni zanesljivi stalnici. Svet se spreminja iz minute v minuto. Edina stalnica, za katero lahko z gotovostjo trdimo, da je zanesljiva, je sprememba, ki jo prinaša jutrišnji dan. Ta bo gotovo drugačen od današnjega.
Pri vseh spremembah, s katerimi se srečujemo, je težko ohranjati uravnotežen pogled na svet in slediti novostim. Živimo v tehnološko razviti družbi, v kateri so se navade in življenjski slog drastično spremenili pod vplivom tehničnega razvoja. Živimo v postmoderni in multikulturni družbi, v kateri se prepletajo pogosto nasprotujoči si pogledi, kulture in 
načini življenja. Živimo v globalni družbi, v kateri gospodarski razvoj premika ravnotežje moči z enega konca sveta na drugega, in to $\mathrm{v}$ manj kot desetletju (Schollaert, 2006). $\mathrm{Na}$ enem koncu ždi rigidnost, na drugem kaos (Stacey, 1996). Michael Fullan (1999) zgovorno povzema, da se »učenje zgodi na robu kaosa«. Teorija kaosa ali teorija kompleksnosti dramatično učinkuje na razumevanje spremembe. Realnost je takšna, kot je, zaradi ravnotežja med številnimi med seboj odvisnimi elementi, ki vplivajo drug na drugega in celo prehajajo drug v drugega (Hoban, 2002). Vsak ekosistem, naj gre za podjetje, šolo, ustanovo ali svet, v katerem živimo, proizvaja številne realnosti, ki vplivajo druga na drugo. $\mathrm{V}$ vsakem od teh ekosistemov obstaja nabor elementov, ki sami sebe ohranjajo v občutljivem ravnotežju. Komaj zaznaven premik na enem koncu vpliva na to, kaj se zgodi na drugem. Če velja, da metulj, ki razširi svoja krila v deževnem gozdu ob Amazonki, sproži tisti drobec dodatne energije, ki $\mathrm{v}$ jugovzhodni Aziji učinkuje tri tedne pozneje, potem mora veljati isto za posameznikove napore. Osebni prispevek k družbi, dodan številnim naporom drugih, je lahko tisti komaj zaznavni premik, ki sproži pomemben nov razvoj, ta pa je lahko odločilnega pomena za življenje mnogih ljudi (Schollaert, 2006).

\section{NOVE DIMENZIJE ZNANJA}

Znanje je nedvomno naše največje bogastvo. $\mathrm{V}$ današnjem, informacijskem obdobju, ko neznanje na nekem področju šteje praktično kot zavestna odločitev, se znanje vse bolj uveljavlja kot pozicijska dobrina. Več znanja kot posameznik ima, več ustvarjalnih možnosti se mu odpira za rast, napredek, prosperiteto in razvoj. Znanje je od nekdaj veljalo za gonilo napredka, najsi gre za razvoj družbe, gospodarstva, lastne osebnosti najsi za razvoj podjetja oziroma organizacije, kjer zaposleni v okviru znanja, ki ga imajo, sproščajo svojo ustvarjalnost. Trstenjak v Psihologiji ustvarjalnosti proučuje vzročno povezanost med znanjem in inteligenco, kjer postavlja $\mathrm{v}$ ospredje navedbo, da inteligence posameznika ne moremo neposredno zajeti zgolj z reševanjem temu namenjenih testov IQ. Meni, da rezultati omenjenih meritev prikazujejo predvsem stopnjo določenega znanja, ne pa inteligence same. Inteligenco posameznika tako opredeljuje kot »odprt sistem možnosti, $\mathrm{v}$ okviru katerih razodeva in razširja svoje znanje $\ll$ (Trstenjak, 1981: 82).

Znanje ima v sodobni družbi posebno pomembno mesto; postaja namreč dobrina, ki ni le pravica, temveč nujnost za vsakogar, zato ne pripada več le izobraževalnim ustanovam, temveč celotni družbi. S tem se spreminja vloga znanja, posledično pa tudi njegov vpliv na sistemsko naravnanost družbe. Po eni strani se danes pri učenju in izobraževanju poudarja individualizacija procesa učenja, saj gre predvsem za intenzivnejše razvijanje posameznikovih lastnosti in potencialov, spodbujanje osebnostne rasti, avtonomije, neodvisnosti; gre torej za krepitev fenomena individualne funkcije izobraževanja, ki nadomešča družbeno funkcijo izobraževanja (Blackledge, Hunt, 1985). Po drugi strani pa čedalje bogatejše individualno znanje spodbuja nastajanje novih možnosti za učenje in izobraževanje, kar zdaj olajšuje tudi ustrezno razvita tehnologija. Nove, alternativne možnosti učenja vplivajo na drugačno pojmovanje vloge znanja in izobraževanja v družbi; čedalje bolj se uveljavlja dostopnost izobraževanja. Tako se krepita zamisel in pobuda o ustvarjanju učeče se družbe, ki temelji na strategiji vseživljenjskega učenja. S tem postaja opaznejša tudi družbena razsežnost izobraževanja, ki ni več pogojena zgolj z izbranim socialnim okoljem in ekonomskim položajem. Izobraževanje in učenje 
postajata osrednja dejavnika, ki lahko zmanjšata odtujenost in neenakost. Z uveljavljanjem učeče se družbe postajajo posamezniki učeči se posamezniki, organizacije pa učeče se organizacije (Jelenc Krašovec, 2003).

\section{ZNANJE KOT KLJUČNI KAPITAL ORGANIZACIJE}

Kadar primerjamo delovanje klasične ekonomske teorije z znanjem, ugotovimo, da prihaja do odstopanj $v$ razumevanju dosedanje kapitalske logike, saj se znanje očitno obnaša nekoliko drugače kot klasični kapital. Znanje lahko brezmejno oplemenitimo, njegova vrednost pa lahko ravno tako narašča, stagnira ali pada kot vrednost kapitala v klasičnem pomenu. Enako je s celotnim intelektualnim kapitalom. Omeniti je treba, da teorije intelektualnega kapitala govorijo o intelektualnem kapitalu le v primeru, kadar se ta povečuje oziroma ustvarja novo vrednost, kar se ne sklada z dosedanjo kapitalsko logiko. Prav tako je v nasprotju s finančnim kapitalom dejstvo, da se znanje z uporabo ne porablja, temveč se le povečujeta njegova širina in globina, hkrati se $\mathrm{z}$ uporabo znanje plemeniti. $Z$ vidika trga znanja lahko znanje pojmujemo v klasičnem tržnem smislu, saj ga lahko tržimo, prav tako ima svojo ceno, ki je odvisna od ponudbe in povpraševanja. Kljub temu je trg znanja zelo kompleksen in specifičen. Seveda obstajajo tudi skupne točke med znanjem kot kapitalom in klasičnim finančnim kapitalom. Kadar znanje postavimo v kapitalsko logiko, se slednje plemeniti na isti način kot finančni kapital. Tudi znanje je namreč treba čim bolj pogosto obračati, saj se le tako oplemeniti (Mihalič, 2006: 111).

\section{Vrste in značilnosti znanja}

Avtorji, ki proučujejo menedžment znanja, opredeljujejo znanje na različne načine.
Sitarjeva (2006: 59) povzema ugotovitve drugih avtorjev in opredeljuje znanje kot nenehno spreminjajočo se mešanico naših izkušenj, vrednot, informacij in strokovnega razumevanja, ki sestavlja ogrodje, v katerega dodajamo in vrednotimo nove izkušnje in informacije. Znanje izvira iz misli posameznikov, zato je predvsem intuitivno in ga je težko izraziti z besedami. Oblikovanje znanja vedno teži $\mathrm{k}$ odkrivanju resnice, izhaja iz naših izkušenj in je tesno povezano $\mathrm{z}$ našo inteligenco in dejanji, zajema naše razumevanje stvari in se navezuje na kontekst, ki smo ga izoblikovali v naših mislih.

$\mathrm{Z}$ vidika menedžmenta znanja je $\mathrm{v}$ teoriji in praksi najpogosteje omenjena delitev, ki ločuje znanje na eksplicitno izraženo, ki ga lahko prosto prenašamo po organizaciji z različnimi mediji, in tisto, ki je skrito $\mathrm{v}$ posamezniku, zato mu pravimo tiho, skrito znanje.

Eksplicitno (izraženo, artikulirano, kodirano, zapisano) znanje je $v$ organizacijah formalno in sistematično zajeto $\mathrm{v}$ specifikacijah izdelkov, znanstvenih formulah, računalniških programih. Lahko ga prepoznamo, opredelimo, shranimo in Menedžment
znanja je del
celotnega procesa
menedżmenta. prenašamo z namenom nenehne uporabe. Do eksplicitnega znanja laže dostopamo, je tudi bolj razumljivo, laže ga obdelujemo in shranjujemo v podatkovnih bazah (Sitar, 2006: 63).

Nasprotno pa implicitno (tiho, skrito, neizraženo, nekodirano) znanje vpliva na sposobnost posameznika in organizacije, da inovira in se nenehno prilagaja. Tiho znanje sestavljajo naše izkušnje, intuicija, individualno razumevanje stvari okrog nas, vse, kar je globoko zakoreninjeno v nas, naših dejanjih in čustvih. Težko ga je dokumentirati, vendar to še ne pomeni, da ga sploh ni mogoče prenašati. Pomembno 
je, da način prenosa prilagodimo in v ospredje postavimo osebno komunikacijo, opazovanje in posnemanje. Zato moramo najprej prepoznati strokovnjake, ki določeno znanje imajo, in preostalim omogočiti neposreden stik z njimi (Sitar, 2006: 64).

\section{Menedžment znanja}

Pri proučevanju menedžmenta znanja kot vedi govorimo predvsem o multidisciplinarnem pristopu k obravnavanju poslovanja organizacije, ki v sebi združuje različna znanstvena področja, kot so psihologija, sociologija, informacijske znanosti, ekonomija ipd.

Možina (2006: 131) opredeljuje menedžment znanja kot del celotnega procesa menedžmenta, ki se osredotoča na sistematično analizo, načrtovanje, pridobivanje, ustvarjanje, razvijanje, shranjevanje in uporabo znanja $\mathrm{v}$ organizaciji. Pri tem poskuša čim večji del človeškega kapitala organizacije preoblikovati v njen strukturni kapital, s čimer pomaga pri razvijanju konkurenčne prednosti organizacije ter ji omogoča, da smotrno dosega cilje.
S konceptom menedžmenta znanja želi menedžment uvesti izboljšave na različnih področjih $\mathrm{v}$ organizaciji. $\mathrm{V}$ ospredju so predvsem zahteve po povečanju organizacijske učinkovitosti in izboljšanju konkurenčnega položaja (Kovač, 2006: 118).

\section{Vloga strateškega menedžmenta v znanjskih organizacijah}

Primerna količina in vsebina znanja sta potreben, ne pa tudi zadosten pogoj za uspešno delovanje organizacije; nadaljnji pogoj je učinkovito udejanjanje znanja v skladu s strateškimi usmeritvami organizacije $\mathrm{v}$ proizvode, ki dajejo partnerjem organizacije večje in boljše koristi kot konkurenčni. Neuporab(lje)no znanje nima vrednosti in ne prinaša koristi. Za uspešnost organizacije, zlasti znanjske, je usodno pomembno prenašanje znanja $\mathrm{v}$ delovanje (Tavčar, 2006: 29-30).

Tavčar (2006: 30) tudi poudarja vlogo udejanjanja znanja kot najpomembnejšega sredstva za uspešno delovanje organizacije in hkrati postavlja pod vprašaj delovanje menedžmenta, ki

Slika 1: Procesni model menedžmenta znanja sodobne organizacije

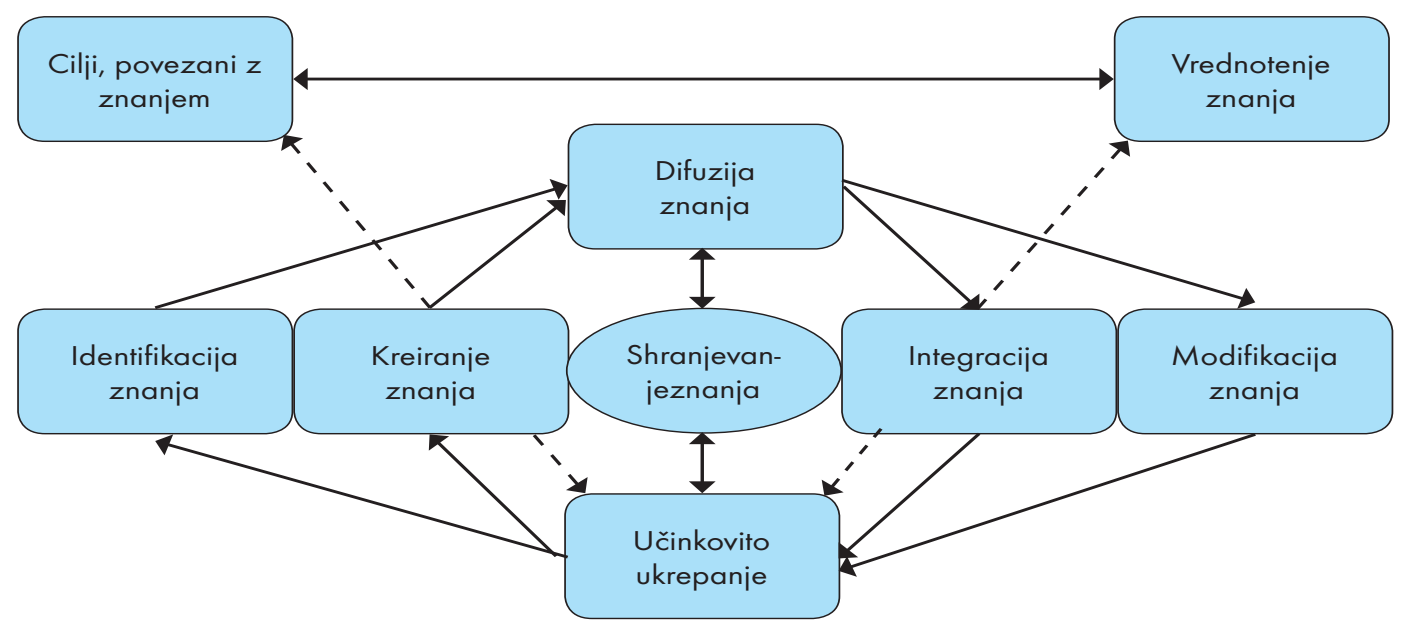


je pogostokrat, predvsem $\mathrm{v}$ manjših znanjskih organizacijah, v pristojnosti strokovnjakov s področja, na katerem deluje organizacija. Zaradi tega je obvladovanje mnogih znanjskih organizacij, tudi večjih, vrhunskih in uglednih, žal zelo pomanjkljivo. Slabo obvladovanje praviloma prinaša slabšo učinkovitost in uspešnost delovanja, mnogokrat slabo vodenje in uravnavanje odnosov med ljudmi, slabo gospodarjenje itn. Navaja, da so ožja strokovna znanja potrebna in dragocena, vendar z njimi ni mogoče obvladovati organizacije, ki je po svoji naravi zapletena, dinamična in mnogokrat nepredvidljiva. Poleg strokovnih znanj morajo menedžerji, ki obvladujejo znanjske organizacije, imeti tudi širša, celostna vseobsežna znanja o obvladovanju organizacij. Ker je obvladovanje ljudi v znanjskih organizacijah praviloma zahtevnejše kot drugod, morajo imeti menedžerji znanja in zmožnosti za vodenje ljudi. V znanjskih organizacijah temeljijo notranji odnosi na zaupanju, lastniki zaupajo obvladovanje svojega premoženja le tistim menedžerjem, ki so vredni zaupanja. Pogoj za zaupanje pa so poštenje, verodostojnost, etičnost. Tako se strateški menedžment $v$ današnji dobi znanja bistveno razlikuje od tistega $\mathrm{v}$ zgodnjih in srednjih obdobjih tako imenovane industrijske revolucije, kjer so prevladovala toga pravila, normativi in obremenjenost z dokumentacijo. Za znanjske organizacije je primerno vseobsežno, na pomembne zadeve osredinjeno obvladovanje, medtem ko je strateški menedžment usmerjen na ljudi, značilnosti njihovega vedenja in obnašanja - tako posamič kot v skupinah.

\section{IZOBRAŽEVALNI MENEDŽMENT: ORGANIZACIJSKO UČENJE IN SISTEMATIČNO USPOSABLJANJE}

V smislu dolgoročnega načrtovanja poslovanja se je primerno vprašati, kakšno znanje,

Slika 2: Zmožnosti in znanja za obvladovanje organizacije

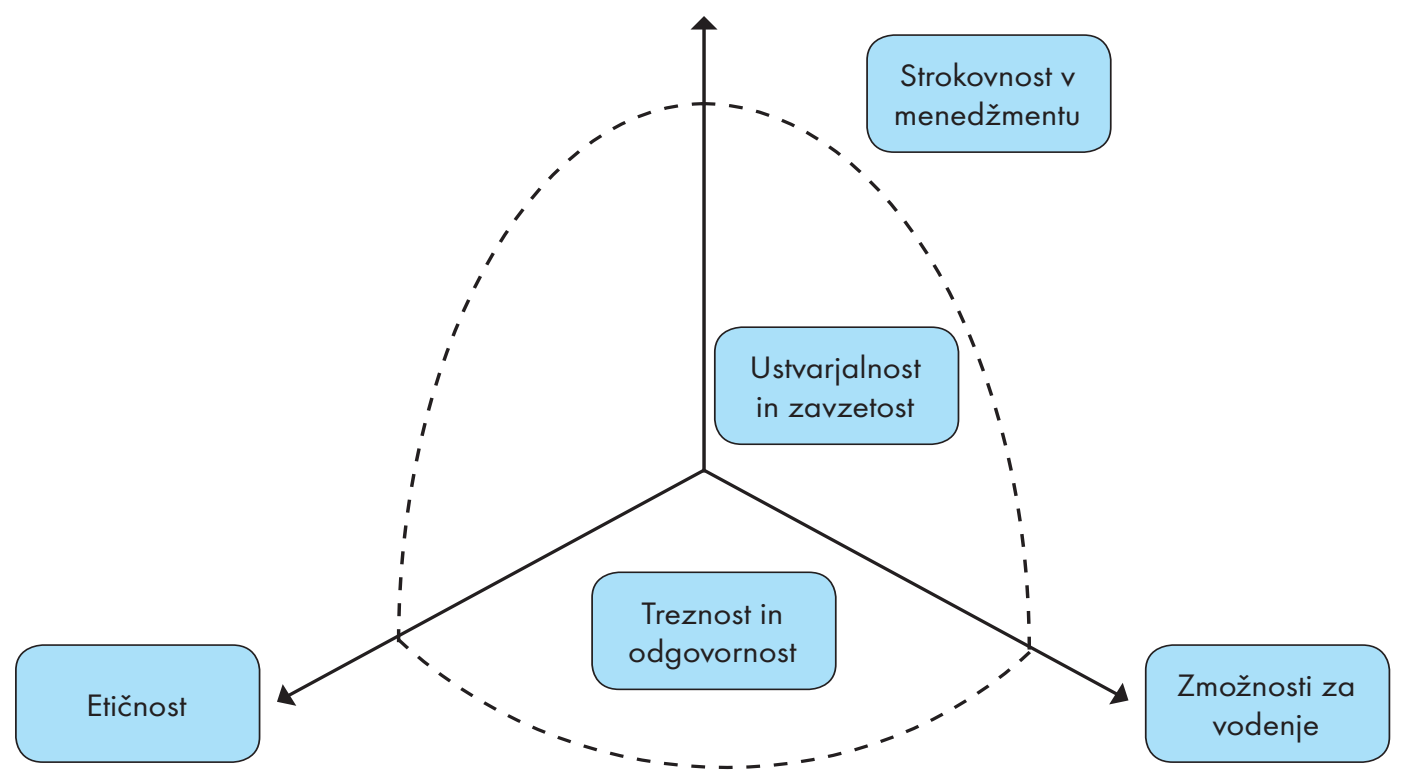

Vir: Tavčar, 2006: 30 
veščine in sposobnosti morajo imeti zaposleni, če želimo uresničiti zastavljene strateške cilje organizacije. Izobraževalni menedžment po mnenju Mihaličeve (2006: 116-117) zaobjema funkcije načrtovanja, organiziranja, vodenja in nadzorovanja procesov izobraževanja, izpopolnjevanja in usposabljanja.

Poznavanje trenutne razvitosti človeških virov in ugotavljanje razlik med dejansko in želeno situacijo omogoča določanje temeljnih izobraževalnih potreb ter v skladu z ekonomskimi možnostmi oblikovanje razvojne projekcije. Na podlagi kriterijev za proučevanje potreb po izobraževanju/učenju pripravo in izvedbo izobraževalnih dejavnosti v organizaciji presojamo sistematičnost in načrtno pristopamo k zadevi. Aktivno poseganje organizacije v zajemanje, širjenje, ustvarjanje in shranjevanje znanja ter uvajanje vseživljenjskega učenja omogočata stalno (re)usposabljanje zaposlenih (Urh, 2007: 52).

\section{Cilj izobraževal- nega menedžmen- ta je povečanje ta je povečanje kompetenc vseh zaposlenih.}

Usposabljanje opredeljujemo kot sistematično razvijanje tistih znanj in veščin, ki jih posamezniki potrebujejo za opravljanje svojega dela. Razumevanje usposabljanja se je skozi zgodovino spreminjalo. Posledično so se $\mathrm{v}$ podjetjih spreminjali tudi pristopi $\mathrm{k}$ njegovemu izvajanju. Sprva je bilo usposabljanje predvsem enosmerno posredovanje tehničnih veščin, v današnjem času pa je postalo pomembna sestavina kompleksnejših procesov učenja in razvoja. Ti omogočajo pridobivanje veščin, pa tudi širšega znanja in ustreznih stališč. Usposabljanje je dandanes umeščeno v družbeni kontekst in vključuje različne procese pretvarjanja znanja. Poleg tega se uveljavljajo prepričanja, da so zaposleni za učenje in svoj razvoj odgovorni sami, uresničujejo pa ju v partnerstvu s sodelavci, nadrejenimi in podjetjem (Dermol, 2010: 11).

Mihaličeva (2006: 116) navaja ključne naloge vsakega sodobnega izobraževalnega menedžmenta $v$ znanjskih organizacijah:

- upoštevanje ne le potreb organizacije, temveč tudi potreb zaposlenih,

- velika prizadevanja za usklajevanje interesov podjetja $\mathrm{z}$ individualnimi,

- intenzivna uporaba primerjave (benchmarkinga) na tem področju,

- $\quad$ sistematično spodbujanje permanentnega izobraževanja,

- usposabljanje za samostojno učenje,

- vzpostavljanje sistemov kontinuiranega učenja,

- poudarjanje interdisciplinarnosti znanj,

- usposabljanje za obvladovanje sprememb in hitro prilagajanje spremembam,

- odpravljanje stanj samouspavanja na pridobljenem znanju,

- merjenje dejanskih učinkov izobraževanja na dodano vrednost ter

- razvoj sistemov izobraževanja in usposabljanja za prihodnost.

Temeljni cilj izobraževalnega menedžmenta je doseči povečanje usposobljenosti in razvoj kompetenc vseh zaposlenih za kakovostno opravljanje dela, kar vodi k ustvarjanju dodane vrednosti. Namen poglabljanja in plemenitenja znanja navsezadnje vpliva na ustvarjalno produktivnost zaposlenih, kar omogoča stabilnejše pozicioniranje organizacije na trgu dela, kjer so inovacije in pravočasen odziv na vedno kompleksnejše potrebe okolja stalnica, če ne že kar pravilo.

\section{Menedžerji znanja}

Mihaličeva (2006: 114-115) poudarja nujnost in pomembnost profiliranja strokovnega nosilca razvoja menedžmenta znanja, 
ki potrebuje široka znanja tudi na področju upravljanja človeškega kapitala, splošne organizacije, komunikologije, vodenja, organizacijske psihologije, prava in splošnega menedžmenta. Vlogo sodobnega menedžerja enači s poklicem prihodnosti v vseh na znanju temelječih organizacijah, to je menedžerjem znanja. Menedžer znanja kot specialist je hkrati v vlogi upravljanja izobraževanja iz naslova funkcij izobraževalnega menedžmenta in v vlogi upravljanja znanja iz naslova funkcij menedžmenta znanja.

Sodobni menedžer znanja skrbi za razvoj menedžmenta znanja v okviru razvoja človeškega kapitala, načrtuje, organizira, vodi, nadzoruje in analizira procese pridobivanja znanj in aplikacije teh znanj v praksi. Hkrati razvija in uvaja nove metode in tehnike izobraževanja v praksi, skrbi za permanentno izobraževanje vseh zaposlenih, oblikuje razvojno vizijo, politiko ter strateške, taktične in operativne cilje na področju upravljanja znanja, pripravlja predloge za spremembe v izobraževanju, skrbi za razvojno in raziskovalno dejavnost na področju menedžmenta znanja, uvaja modele odličnosti pri upravljanju znanja ter oblikuje koncepte in metodologijo za uspešno integracijo vseh procesov gospodarjenja z znanjem. Ključna naloga menedžerja znanja je usklajevanje obstoječih, želenih in zahtevanih znanj glede na organizacijske vloge, ki jih zaposleni zasedajo, oziroma za katere se predvideva, da jih bodo zasedali v prihodnje. Na tej točki je posebno pomembno sodelovanje menedžerja znanja pri pripravi kariernih načrtov posameznikov, izvedbi letnih razgovorov, oblikovanju in izvedbi individualnih načrtov izobraževanja, izdelavi kompetenčnih načrtov ter pri pripravi sistemov napredovanja in nagrajevanja (Mihalič, 2006).

Največji izziv pri uvajanju vsega omenjenega v prakso je $\mathrm{v}$ doseganju psihološkega ozračja, ki zaposlene usmerja $\mathrm{k}$ permanentnemu izobraževanju. Menimo, da bi vzpostavitev partnerskega odnosa, ki temelji na vzajemni sinergiji med zaposlenimi na eni strani in skrbniki znanja oziroma menedžerji na drugi, zagotovila dovolj močno vez za oblikovanje razmer, ki bi spodbujale ustvarjanje, prenos in izmenjavo (vedno) novega znanja. Menedžerji

Slika 3: Spodbujanje ustvarjalnosti in pridobivanja znanja s sinergijskim (so)delovanjem

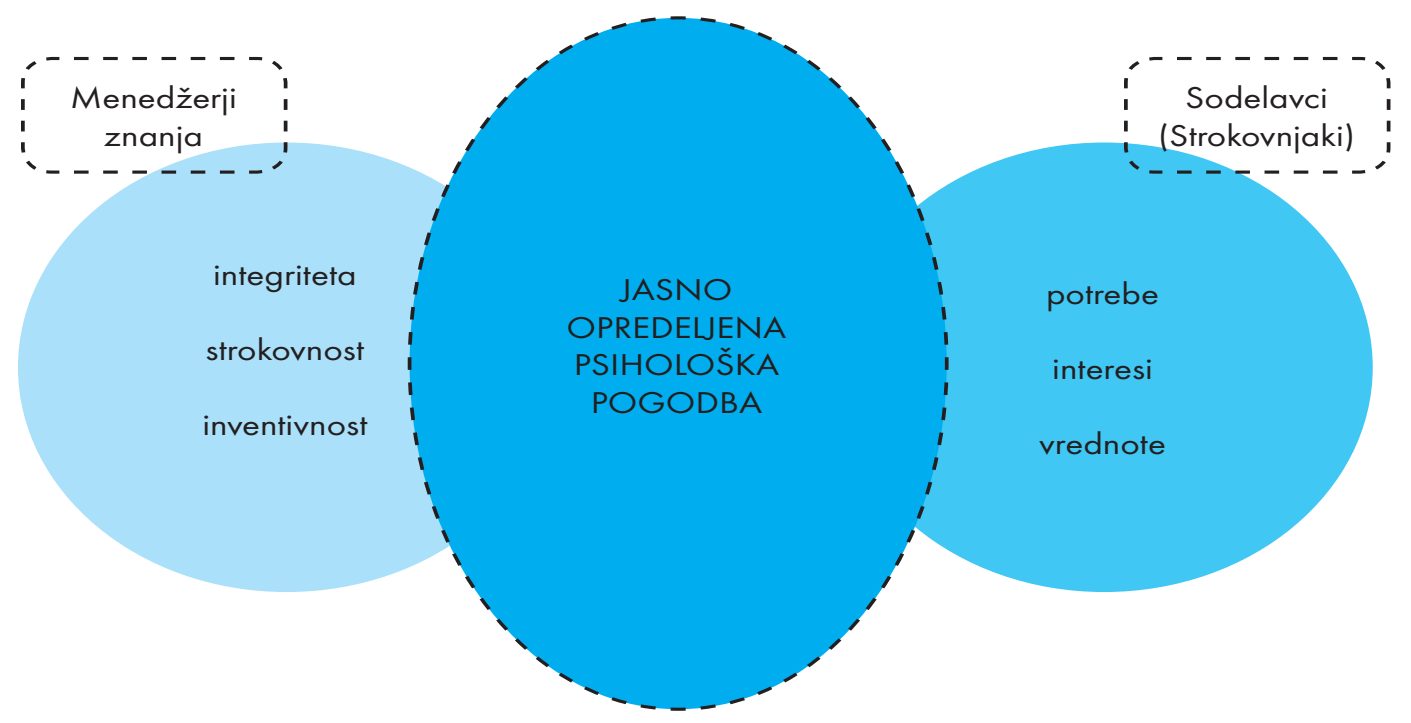


naj delujejo na podlagi osebne integritete in strokovnosti, ki zahteva nenehno nadgrajevanje obstoječega znanja. Le tako si lahko pridobijo visoko stopnjo zaupanja, kar je pogoj za zgraditev kakovostnih medsebojnih odnosov. Vsebina partnerskega odnosa naj bo konkretno, jasno in nedvoumno opredeljena z realno zastavljeno psihološko pogodbo, ki naj bo pregledna in razumljiva za obe strani. Doseženo ravnovesje kot posledica verodostojne in jasno opredeljene psihološke pogodbe med vodstvom in zaposlenimi se kaže v inovativno razmišljajočem kadru. Inovativno razmišljajoč kader pa potrebuje inventivno vodstvo. Po mnenju Sriće (1999: 193) lahko zgolj inventiven menedžer s svojim znanjem, lastnostmi, metodami in vizijo motivira sodelavce in jih spodbuja k ustvarjalnemu opravljanju njihovega dela.

\section{Znanje za gospodarski razvoj}

Temeljni pogoj za prehod v družbo oziroma gospodarstvo, ki temelji na znanju, je dovolj veliko število usposobljenih kadrov. V mednarodnem okolju se vse več pozornosti namenja vprašanju človeških virov kot tudi spodbujanju razvoja, ki se navezuje na tehnološki napredek in raziskovalno dejavnost. Človeški viri, vpeti v razvojno-raziskovalno dejavnost, so eni izmed ključnih dejavnikov za ohranjanje konkurenčnosti na makro ravni gospodarstva. Ugotovitev se nanaša tako na Slovenijo kot tudi Evropsko unijo, katere ambicija je postati najbolj konkurenčna regija na svetu. Po mnenju Bevčeve (Bevc, Koman in Murovec, 2006: 209) iz tega sledi, da je na eni strani treba vzdrževati določen obseg »proizvodnje« človeških virov v raziskovalno-razvojni dejavnosti in na drugi strani spremljati gibanja, da bi zaznali pomanjkljivosti v ponudbi in uporabi teh redkih visoko usposobljenih človeških virov. Šele na tej podlagi je namreč mogoče oblikovati jasno strategijo razvoja človeških virov in voditi učinkovito politiko, ki se po zgledu dobrih praks (Finska, Bavarska) navezuje na scenarij, ki pomeni ključ do uspeha; to je do razcveta razvojno-raziskovalne dejavnosti in gospodarstva $\mathrm{v}$ celoti.

\section{LITERATURA}

Bevc, M., Koman, K., Murovec, N. (2006). Človeški viri v razvojno-raziskovalni dejavnosti v Sloveniji in primerjava z državami Evropske unije. Ljubljana: Inštitut za ekonomska raziskovanja.

Blackledge, D., Hunt, B. ( 1985). Sociological Interpretation of Education. London, New York: Routledge.

Dermol, V. (2010). Vplivi usposabljanj na učenje v podjetju in na njegovo uspešnost. Celje: Mednarodna fakulteta za družbene in poslovne študije.

Fullan, M. (1999). Change Forces: The Sequel. London: Routledge.

Hoban, G. (2002). Teacher Learning for Educational Change. Buckingham: Open University Press. Jelenc Krašovec, S. (2003): Univerza za učečo se družbo. Ljubljana: Sophia.

Kovač, J. (2006). »Organizacijske razsežnosti menedžmenta znanja«. V: Možina, S. (ur.), Menedžment znanja na poti $k$ učečemu se podjetju. Maribor.

Mihalič, R. (2006). Management človeškega kapitala. Škofja Loka: Mihalič in Partner.

Možina, S. (2006). »Vloga menedžmenta znanja v organizaciji«. V: Možina, S. (ur.), Menedžment znanja na poti $k$ učečemu se podjetju. Maribor.

Sitar, A. (2006). »Oblike in razsežnosti znanja v organizaciji«. V: Možina, S. (ur.), Menedžment znanja na poti $k$ učečemu se podjetju. Maribor.

Srića, V. (1999). Ustvarjalno mišljenje. Ljubljana: GV Založba.

Schollaert, R., ... in drugi. (2006). Vpeljevanje spremembe v šole - konceptualni vidiki. Ljubljana: Zavod Republike Slovenije za šolstvo, 2006.

Stacey, R. (2003). Strategic Managemnet and Organizational Dynamics. London: Pitman. 
Tavčar, M. (2006). »Strateški menedžment znanja«. V: Možina, S. (ur.), Menedžment znanja na poti $k$ uс̌есети se podjetju. Maribor.

Trstenjak, A. (1981). Psihologija ustvarjalnosti. Ljubljana: Slovenska matica.

Urh, I. (2007). »Kriteriji za oceno organizacije/institucije kot učeče se organizacije«. Organizacija, 40: 45-58.

1. Pri psihološki pogodbi gre za sklop prepričanj o materialnih in nematerialnih nagradah, ki jih zaposleni pričakujejo v zameno za svoje delo. Pričakovanja so odvisna od njihovih potreb, vrednot in interesov. Z odprto komunikacijo in zaupanjem lahko menedžer znanja (s podporo preostalega vodstva) vpliva na to, da so razlike med ponujenim in pričakovanim čim manjše, s čimer se izognemo nepotrebnim konfliktom in padcu motivacije. 